\title{
Unemployment in South Africa: The Nature of the Beast
}

Geeta Gandhi Kingdon and John Knight

September 2003

Centre for the Study of African Economies

Department of Economics

University of Oxford

\begin{abstract}
Summary
Unemployment in South Africa is so widespread that it demands an explanation. This paper examines a central question about South African unemployment. Why do the unemployed not enter the informal sector, as is common in other developing countries? The data do not support the idea that unemployment is largely voluntary. The policy implications - that government should diminish labor market segmentation and the obstacles to entering the productive informal sector - may be relevant also to other developing countries with high unemployment.
\end{abstract}

Keywords: unemployment, informal sector, reservation wages, South Africa, Africa

\section{Acknowledgements}

This paper has benefited from the comments of participants at the Trade and Industrial Policy Secretariat Conference, South Africa; the American Economic Association's Annual Meeting; and the Labor Economics Seminar, University of Oxford. We are grateful to anonymous referees whose comments led to further improvements. The research was supported by a grant from the U.K. Department for International Development.

\section{Correspondence:}

Geeta Kingdon, Department of Economics, University of Oxford, OX1 3UQ, U.K.

Tel: 44-1865-271065 (work); 44-1235-522641 (home)

Fax: 44-1865-281447; email: geeta.kingdon@economics.ox.ac.uk 


\section{UNEMPLOYMENT IN SOUTH AFRICA: THE NATURE OF THE BEAST}

\section{INTRODUCTION}

Unemployment in South Africa is remarkably high, and rising. In 2002 it was officially measured at $41 \%$ on the broad definition and $30 \%$ on the narrow definition (StatsSA, 2002). This is different to the pattern that exists in most developing countries, where paucity of formal sector jobs manifests itself in large informal sectors rather than in high levels of open unemployment. Table 1 shows that South Africa is an international outlier in this respect: it has a small informal sector and widespread open unemployment so that its ratio of non-agricultural informal sector employment to urban unemployment is tiny compared to that in most developing countries.

Unemployment is potentially a matter of serious concern - for its effects on economic welfare, production, erosion of human capital, social exclusion, crime, and social instability. Some view the level of unemployment and its rise as the most serious threat facing South African society and its governance. However, the potential costs of unemployment depend on the nature of the beast. The underlying question we address is this. Is unemployment in South Africa largely voluntary or involuntary? The answer has important ethical and policy implications. If unemployment is voluntary, it is arguable that its cure can be downgraded as a policy concern. Interest groups and ideologues have taken predictable stances but the issue has not been addressed rigorously in South Africa.

In Section 2 we explain the hypotheses to be investigated, placing them within the general and the South African literature. We go on to pose the question: why is informal sector employment so low and unemployment so high in South Africa? Section 3 examines whether the unemployed would have higher income, and be happier, in self-employment. Finding that they would, in Section 4 we consider possible barriers that might prevent them from entering the informal sector. Section 5 concludes, both for South Africa and more generally.

Whereas in the past, the absence of reliable nationally representative household-level data has prevented empirical analysis of such issues in South Africa, the recent availability of rich household survey data collected by the South African Labour Research Unit (SALDRU) and the Central Statistical Service (known as Statistics South Africa) allows us to explore these issues. We use survey data 
collected in 1993, 1994 and 1997, described in Kingdon and Knight (2001a) and data from Labour Force Surveys up to 2002.

[Table 1 about here]

\section{HYPOTHESES}

Although the theoretical distinction between voluntary and involuntary unemployment is entrenched in the literature, the notion that one can judge whether unemployment is voluntary or involuntary has been questioned (Layard et. al., 1991). Notwithstanding the theoretical difficulties, Clark and Oswald (1994) and Theodossiou (1998) approach this question in the psychologists' tradition by examining the utility levels of the jobless. They find that unemployed persons in various developed countries have much lower levels of happiness or wellbeing than those in work, and accordingly reject the hypothesis that unemployment is voluntary. A number of economists refute the notion advanced by Benjamin and Kochin (1979) that a good proportion of interwar unemployment in Britain was voluntary and based on generous unemployment benefits (see papers by Cross; Collins; Metcalf, Nickell and Floros; and Ormerod and Worswick, in the Journal of Political Economy, 1982). Crafts (1987) argues that much of interwar unemployment in Britain was involuntary long-term unemployment which was not associated with high replacement ratios, with being well-off or with voluntary search: the lack of search was, for the most part, a result of discouragement - a choice made under duress.

A typical view of unemployment in developing countries is that much open unemployment is due to search and is voluntary (Harris and Todaro, 1970; Harris and Sabot, 1982). Probabilistic models of rural-urban migration produce an equilibrium level of urban unemployment. The equilibrium condition is that, with the urban formal sector wage above the competitive level, the 'expected wage' (the formal sector wage multiplied by the probability of obtaining formal sector employment) equals the rural supply price. It might appear that the existence of a free-entry urban self-employment sector rules out the possibility of there being equilibrium unemployment. However, positive unemployment can arise because self-employment income is too low, or because the probability of securing wage employment is higher if search is conducted from open unemployment than from self-employment, or because self-employment is regarded with disdain. If formal sector job-search from unemployment is 
more efficient than from informal employment, those able to afford unemployment may choose to remain openly unemployed. However, the poor cannot afford to do so. If most unemployment in the economy is of this search variety, the inter-household relationship between unemployment and income is likely to be positive insofar as the informal sector absorbs the poor. It is an important question with serious policy implications: does the typical view of unemployment in developing countries apply to South Africa, and to others with high unemployment?

The nature of unemployment in South Africa has attracted a literature. In the early 1980s there was a heated debate over whether unemployment in rural areas was voluntary or involuntary. On one view, much of it was voluntary: at least part of the labor market cleared and rural-dwellers chose to be unemployed because of the income available from household agriculture (Kantor, 1980; Gerson, 1981). This view was challenged by others (Knight, 1982; Simkins, 1982) who pointed to the lack of productive activities available at the margin to rural-dwellers. The issue was by no means settled and the debate has continued in recent times. For example, an ILO report on the South African labor market (ILO, 1996, p111) raises the notion that people with access to non-earned income may be voluntarily unemployed. The issue has also arisen in the debate about the appropriate definition of unemployment whether to use the narrow measure (excluding the unemployed who wanted work but did not search actively in the reference period) or the broad measure (including this group). In 1998 it made a difference between an unemployment rate of 26 per cent and one of 39 per cent. The same ILO report (ILO, 1996, p104) suggests that including the non-searching unemployed may exaggerate the level of unemployment, implying that the broad measure includes people who are out of the labor force. Similarly, the South African Statistical agency's recent decision (StatsSA, 1998, p1) to drop the nonsearching unemployed from the official definition of unemployment and from the denominator in calculating the unemployment rate implicitly assumes that such people have voluntarily withdrawn from the labor force.

We provide a simple theoretical framework within which to set our empirical analysis. Figure 1, derived from Layard et. al. (1991), explains why unemployment can be simultaneously voluntary and involuntary. For simplicity, the total labor force - the employed plus the unemployed - is assumed to be constant and equal to LL' on the horizontal axis. All workers are willing to work in the 
primary sector. The demand $D_{1}$ for primary sector employment is a function of the primary sector wage, set at $W_{1}$ by efficiency wages or union bargaining. Thus primary sector employment is shown by $L N_{1}$. This leaves $N_{1} L^{\prime}$ workers available for the secondary sector. The curve $D_{2}$ shows the demand for labor in the secondary sector as a function of the wage in that sector. The secondary sector labor market is competitive, so that the wage adjusts to clear the market: $N_{2} L^{\prime}$ 'workers are employed at wage $W_{2}$. This leaves $N_{1} N_{2}$ workers unemployed. These people are willing to work in the primary sector at the going wage $W_{1}$ but cannot find work there, but they are unwilling to work in the secondary sector at the going wage, $W_{2}$. They are thus both involuntarily and voluntarily unemployed in this segmented labor market. All workers not employed in the formal sector are involuntarily excluded from it. Among this group, those who choose not to enter the informal sector do so either for leisure or search reasons, i.e. they are voluntarily unemployed. Barriers to entry may exclude unemployed workers from the informal sector. However, provided the informal sector contains at least some free-entry activities, the decision not to enter these activities - based on the derisory income that they offer - is nevertheless voluntary. In a sense, economic behavior is always voluntary: economic agents invariably have at least some room for maneuver and choice. The real question is whether the available set of options is so limited as to render unemployment involuntary for the purpose of forming value judgments and making policies.

[Figure 1 about here]

Workers can be found in three different states: wage employment ( $L N_{1}$ in Figure 1$)$, selfemployment ( $N_{2} L^{\prime}$ ), and unemployment $\left(N_{1} N_{2}\right)$. How do workers choose among them? Consider first the choice between wage employment and unemployment. Given the possibility of redistribution within the household, the distribution of household income according to need creates an incentive for a member to remain needy and thus a disincentive to work. Higher household income, by raising withinhousehold transfers, further encourages the consumption of leisure. Thus there is both a disincentive effect (dependent on the extent of redistribution) and an income effect (dependent on the amount of income available for redistribution). If this 'luxury unemployment' hypothesis is correct, unemployment may be regarded as voluntary. There is a second possible reason why workers might 
choose unemployment rather than wage-employment. It is that the unemployed lack information. In an imperfectly competitive labor market the unemployed face a distribution of wage offers with probabilities attached. They are willing to remain unemployed until a sufficiently high wage offer arrives: at the margin, the expected return from continued search no longer exceeds the cost of search (Stigler, 1962). These forms of unemployment are voluntarily chosen. By contrast, if wage employment is tightly rationed and the probability of securing wage employment is extremely low, workers may be involuntarily unemployed at the going wages. This possibility is suggested by the fact that formal sector wage employment actually contracted in South Africa over the relevant period 19941997 (StatsSA, 1998, p.5-6), and by the graphic example of 39,000 applications for 35 permanent jobs as gardeners and cleaners which were advertised at the University of Cape Town ${ }^{1}$.

Secondly, consider the choice between self-employment and unemployment. In what circumstances would a worker be unemployed rather than self-employed? More specifically, why do unemployed workers in South Africa choose to remain unemployed and to search, or to wait, rather than join the free-entry informal self-employment sector? This informal sector might be an end in itself or a means to wage-employment, i.e. a base from which to search, or wait, for wage-employment. We shall adduce evidence to show that income from wage-employment greatly exceeds income from selfemployment. This suggests that wage-employment is the preferred state. However, income from selfemployment will be shown to exceed income while unemployed. Why then do the unemployed not choose to search from the self-employed state? One possible explanation is that job-search is more efficient if undertaken while unemployed. In that case, unemployment might properly be regarded as voluntary. However, for many unemployed workers access to those informal sector activities that offer higher income may be prevented by barriers to entry. In that case, unemployment may be the least bad activity for such people.

\section{WHY DO THE UNEMPLOYED NOT ENTER THE INFORMAL SECTOR?}

Employment in the informal sector is jointly determined by the supply and demand functions for labor (corresponding to the curves $S_{2} S_{2}$ and $D_{2} D_{2}$ respectively in Figure 1). It is 
nevertheless helpful to distinguish them. One possible reason why the unemployed do not enter the informal sector is that they prefer leisure and can afford it (the supply side). The other is that the unemployed are deterred from entering by barriers to entry (the demand side). The former suggests that unemployment is voluntary, and the latter that it is involuntary. In this section, we explore the relationship between labor market states (unemployment or informal employment), on the one hand, and poverty and perceived quality of life, on the other, in order to choose between the alternative hypotheses.

Our hypothesis testing proceeds as follows. First, we establish that the informal sector is relatively small. Second, we test for, and find, sharp earnings segmentation between the informal and the formal sectors. Third, we ask whether the unemployed are economically worse off than the informally employed, and find that they are indeed relatively deprived. Fourth, we show from the predicted self-employment income of the unemployed that they could gain by entering self-employment. Fifth, we use subjectively measured perceptions of happiness at the household level to show that unemployment depresses happiness whereas self-employment does not. This evidence suggests that the informal sector is not in general a free entry sector: we go on to consider the various possible barriers to entry into informal employment.

[Table 2 about here]

While there is no commonly agreed definition of 'informal sector', for present purposes we take informal workers to be those not in regular employment, that is, workers who are in casual wage employment, domestic service, or agricultural/non-agricultural self-employment ${ }^{2}$. Table 2 shows that by this rough and ready definition, the informal sector absorbs only a very small proportion (19\%) of the (broadly defined or 'broad') workforce and that open unemployment is more common ${ }^{3}$. The recent Labor Force Surveys (LFS) provide a more reliable way of capturing the size of the informal sector in South Africa because they ask more probing questions about self-employment and small business activities than do the SALDRU or October Household Surveys (OHS). Using data from Statistics South Africa contained in Devey, Skinner and Valodia (2002) and supplementing them with the latest available LFS, we find (Table 3) that the informal sector absorbed between 14 and 17 per cent of the broad labor force in the period 1997-99 (based on OHS) but that, using the more probing approach of 
the LFS, the informal sector absorbed between 18 and 24 per cent of the broad labor force during 20002002, with no upward trend ${ }^{4}$. Thus, although the LFS gives somewhat higher estimates, the size of the informal sector in South Africa is still very small by developing country standards. Nor does the proportional size of the informal sector appear much larger when time use data are considered. For example, using Statistics South Africa's Time Use Survey 2000, Wittenberg (2002) concludes that "it is not clear that aggregate unemployment rates will be brought down a lot by correcting for these kind of [informal] activities" and that while "some of the unemployed/not economically active probably do engage in some forms of work, the extent of this is probably not of such a magnitude [as] to solve the unemployment puzzle".

[Tables 3 and 4 about here]

The probability distributions of monthly earnings of informal and formal sector workers show that the distribution of informal earnings lies to the left of the distribution of formal earnings (Figure 2). The ratio of their geometric mean individual earnings (291 and 1017 rands per month) is 1: 3.5. It might be argued that the lower earnings in informal work may be because of inferior characteristics of informal sector workers. We fitted earnings functions for formal sector workers (both OLS and selectivity-corrected ones) ${ }^{5}$ and used these to predict earnings of informal sector workers on the hypothetical basis that they faced the formal sector earnings equation. The results showed that a large part of the formal-informal earnings difference remained after controlling for characteristics, irrespective of whether we used the OLS or the selectivity-corrected earnings functions. The unexplained part (i.e. the difference due to coefficients) was $50 \%$ of the actual difference in mean earnings between the two sectors when we used OLS and $64 \%$ when we used selectivity-corrected earnings equations. This suggests that part of the reason why formal sector earnings are higher than those in the informal sector is that returns to characteristics are higher in the former.

[Figure 2 about here]

Table 4 presents evidence on the relationship between labor market status and both poverty and wider measures of deprivation. It shows that, on virtually every indicator of well-being, unemployed people are very substantially worse-off than the informally employed. For example, per capita monthly household income (expenditure) of the unemployed is only $31.2 \%$ (48.2\%) of the corresponding figure 
for the informally employed. The most appropriate income concept is the share of household income that is made available to the unemployed worker. This might be higher than household per capita income (if an adult receives more than a child) or lower (if an unemployed member is in a weak bargaining position within the household). Insofar as the unemployed take account of their own individual income rather than household income per capita, it is notable that unemployment insurance is very limited in scope, that benefit entitlement lasts for only the first six months, and that only $1.3 \%$ of the unemployed received any unemployment benefit at the time of the survey. Living conditions are also far worse for the unemployed than for the informally employed - in terms of living space, access to drinking water, and the availability of sanitation, electricity, etc.

Table 5 presents the average predicted earnings of unemployed people in informal employment. It presents these separately for people in informal self-employment and in informal wage employment, i.e. among domestic servants and those in other casual wage employment. The coefficients of earnings functions fitted on informal sector workers (self-employed and casual waged workers separately) were used to predict earnings of unemployed persons. The selection term lambda was significant at the $1 \%$ level in both the informal and casual earnings equations, and it was well identified through use of the household demographic variables mentioned in footnote 5. Table 5 shows that, depending on the model used, their predicted earnings in such employment are between 1.44 and 2.35 times their income in unemployment, i.e. their average per capita household income (of R 186 per month, as seen in Table 4) ${ }^{6}$.

\section{[Tables 5 and 6 about here]}

It is arguable that when predicting earnings in informal self-employment, we over-estimate the return to labor by failing to isolate the return to capital in self-employment. In order to identify the marginal return to labor (MRL), we fitted a Cobb-Douglas production function for the sample of the self-employed. For those self-employed persons who reported having no capital (the very smallestscale self-employed operations), their net income from the enterprise is taken as their MRL. The median (mean) MRL per month for this group is R 160 (447). For self-employed persons who use any capital, the median (mean) MRL calculated from the production function is R 188 (1273). Thus, the median return to labor in informal self-employment - with or without capital- is significantly greater than a 
person's median income in unemployment (R 104 per month in Table 4); the same is true of mean values (Table 6). The unemployed are clearly worse off, on average, than they would be in the informal sector. This is also true of the majority of unemployed individuals. We used selectivity-corrected earnings functions fitted for self-employed persons to predict the individual self-employment earnings of the unemployed sample. We then compared these with their individual unemployment income, i.e. their household per capita income, and found that for $87.5 \%$ of the unemployed individuals, predicted monthly informal sector earnings exceeded monthly household per capita income. Some part of the difference may be necessary to compensate for the disutility of effort involved in informal sector employment. Nevertheless, it would be remarkable if the unemployed chose to remain so deprived. It appears that the restricted opportunities for entering the informal sector provide no real alternative to unemployment for most of the unemployed. However, if it were possible to identify those informal sector activities that could indeed be entered freely, we might then find that earnings were inadequate to attract the unemployed.

The voluntary unemployment hypothesis can be further tested following the approach of Clark and Oswald (1994), di Tella et. al. (1998), Theodossiou (1998), and Blanchflower and Oswald (1999) described earlier. Their evidence - coming from the US and Europe - indicates that the unemployed are substantially and significantly less happy than the employed and it is used to suggest that unemployment must be involuntary because people would not choose to be unhappy. Following this literature, we extend the notion that comparing well-being levels across individuals can shed light on the nature of their unemployment. We pose the question: are unemployed people happier than informally employed people? If they are, then it might be possible to argue that their unemployment is the result of choice, and hence voluntary, rather than due to limited opportunities for informal work.

We test the hypothesis for South Africa by examining the impact of the household unemployment rate and the household informal-employment rate on the household's perceived quality of life and poverty, controlling for other factors. The SALDRU survey (SALDRU93) asked households the question: 'Taking everything into account, how satisfied is this household with the way it lives these days?' The five possible responses were 'very satisfied', 'satisfied', 'neither satisfied nor dissatisfied', 'dissatisfied', or 'very dissatisfied'. In order to investigate the impact of unemployment and informal 
sector employment on perceived quality of life, an ordered probit model was used, with 'very dissatisfied' given the value of 0 ; 'dissatisfied' 1 ; 'neither satisfied nor dissatisfied' 2; 'satisfied' 3; and 'very satisfied' 4. Thus, the dependent variable can be interpreted as an index of happiness or of satisfaction with life.

The analysis was carried out using household-level data since the quality-of-life code is available only at the household and not at the individual level ${ }^{7}$. The unemployment variable is the household unemployment rate, i.e. the percentage of labor force participants aged 16-64 within the household who are unemployed. For example, in a household with three labor force participants where one is unemployed, the household unemployment rate is $33 \%$. Thus, the household unemployment rate takes values such as $0,0.20,0.25,0.33,0.40,0.50,0.67,0.75,0.80$, or 1.0 for most households. Other variables in this regression are household variables, cluster variables, or aggregated individual variables averaged across all household members (e.g. average age of all labor force participant members of the household, percentage of household members with higher education, etc).

[Table 7 about here]

Table 7 presents the ordered probit equation for the quality of life (or happiness) index fitted on SALDRU93 data. It shows that, in general, happiness increases with income and education, as found in European and US studies, and is lower for each of the race groups African, colored and Indian, than for whites. Whereas the household unemployment rate significantly lowers household happiness controlling for household per capita income and other factors - the household informal employment rate does not depress it. To the extent that earned income is mediated by employment status, the association of unemployment and happiness is likely to be greater than that seen in the first six columns of Table 7. When household income dummies are excluded (in the last three columns of Table 7), the adverse marginal effect of unemployment on happiness increases from -11 percentage points to -16 percentage points. The negative relationship between household unemployment rate and household happiness might thus be due partly to interdependent utilities among the household members and partly to income sharing which reduces the consumption of the employed members.

It is possible that causality runs in the opposite direction to that we have hypothesized, or that the observed association is non-causal. For instance, unhappy people may be less desirable to 
employers, so that low well-being may be the cause of unemployment rather than its effect.

Alternatively, some unobserved characteristic of the unemployed, such as lethargy, may both make them unhappy and serve as a barrier to leaving unemployment. In the absence of panel data, this objection cannot be ruled out and its importance is a matter of judgment. However, longitudinal evidence for Britain collected by psychologists that sheds doubt on these alternative explanations (Warr, Jackson and Banks, 1988).

A possible objection to the inference that unemployment is involuntary is that formal-sector job-search is an investment in future higher incomes and people may be willing to endure temporary poverty and deprivation in order to engage in full-time job-search. If the unemployed are indeed engaging in such an inter-temporal optimization strategy, then being in unemployment and poverty may still be consistent with voluntary search unemployment. However, data on hours spent in job-search by the unemployed and data on duration of unemployment cast doubt on this interpretation. Only $9 \%$ of the narrowly unemployed searched full-time (35 or more hours) for work in the reference week, and the vast majority (68\%) spent no more than 10 hours in job-search. Thus, it would have been possible for most of the searching unemployed persons to combine job-search with informal sector work.

While the SALDRU93 survey did not ask a question on unemployment duration, the October Household Surveys include a question for unemployed persons on the duration of their uncompleted spell of unemployment. The answers are recorded in categorised form rather than as a continuous variable. The categories in OHS97 data are 'less than 1 month', 'between 1 and 6 months', ' 6 months to 1 year', ' 1 to 3 years' and 'greater than 3 years'. By assigning midpoints of the categories, a duration of unemployment variable 'number of months' has been created. For those who were unemployed for more than 3 years, an arbitrary value of 48 months was assigned ${ }^{8}$. The survey also asked individuals whether they had ever worked previously. Table 8 gives the distribution of duration of unemployment. It shows very long duration of unemployment (>3 years) for $37 \%$ of the unemployed. A further $29 \%$ were unemployed for between 1 and 3 years, so that about two-thirds of all jobless workers were unemployed for more than a year. The mean uncompleted duration of unemployment in 1997 was about 2 years and 2 months and the median was 2 years. The distribution of unemployment duration and its long mean and median, together with the earlier evidence of poverty and lack of well- 
being among the unemployed, casts doubt on the notion that a high proportion of the unemployed are in voluntary unemployment.

[Table 8 about here]

Finally, an ordered probit of duration of unemployment (not presented) was fitted as a function of variables which would influence employability and the cost of search, using the OHS97 data. Even standardizing for these variables, we found a negative relationship between per capita household expenditure and unemployment duration. A Smith-Blundell test failed to reject the exogeneity of the per capita expenditure variable ${ }^{9}$. This evidence suggests that poverty increases unemployment duration, perhaps by inhibiting search. This is consistent with Kingdon and Knight (2000) who show that poverty deters job search activities in South Africa. It is also consistent with the observations of Wilson and Ramphele (1989) who provide substantial anecdotal South African evidence that poverty inhibits jobsearch. These findings cast doubt on the hypothesis that unemployment while in poverty is a chosen search strategy, and they support the hypothesis that unemployment is involuntary.

We went on to test the further hypothesis that persons are unemployed because they have unrealistically high wage aspirations, using information on the reported reservation wages of the unemployed and their predicted wages if they were in formal wage employment. Although about half of the jobless had reservation wages that were higher than the wage they could reasonably expect in wage employment, it is doubtful that many of these were voluntarily unemployed. People appear to report a wage that they regard as fair, or to imagine themselves in a bargaining context, when asked a question about their reservation wage ${ }^{10}$. The reservation wage question contained in the SALDRU survey does not provide a reliable criterion for judging willingness to work $^{11}$.

\section{BARRIERS TO ENTRY?}

While it is possible that formal-work aspirations, greater effectiveness of search from the unemployed than from the informally employed state, and access to non-earned income are reasons why some persons choose to remain unemployed, the evidence of much greater deprivation and unhappiness associated with unemployment than with informal sector employment tells against the idea that much 
unemployment in South Africa is voluntary. It suggests that the informal sector is not generally a freeentry sector, and that there may be barriers which prevent many of the unemployed from entering much of this sector. In this section we examine whether such barriers exist in South Africa.

Several authors note that many activities in the so-called informal sector of developing countries are highly stratified, requiring skills, experience and contacts, with identifiable barriers to entry. For example, petty trading often has highly structured labor and product markets with considerable costs of entry. Banerjee (1986) found that even in urban India, with its large selfemployment sector, entry is not easy. Even when skill and capital are not required, entry can be difficult because of the presence of cohesive networks which exercise control over location and zone of operation. Support for the idea that employment in the informal sector requires skills and capital also comes from Latin America. In his work on Latin American countries in general and on Mexico in particular, Maloney $(1999,2002)$ questions whether the informal sector in Latin America largely comprises involuntary, disadvantaged and under-paid workers, and finds evidence for viewing it more as an unregulated entrepreneurial sector, voluntarily entered even at the expense of lower income. However, in arguing that informal sector workers tend to be older and to enter from the formal sector after they have accumulated knowledge, capital and contacts, he recognizes that lack of experience and capital can be barriers to entry that deter participation in the informal sector.

There is a paucity of evidence on whether the informal sector is a free-entry sector and on why it is relatively small in South Africa. In a survey of 500 informal sector operators in the Johannesburg area in 1999 , it was found that $50 \%$ had previously been long term unemployed and only $36 \%$ had previous work experience (Chandra et al., 2002, p. v). This suggests that it is possible for at least some of the unemployed to enter the informal sector. The respondents listed crime, lack of access to credit, lack of access to infrastructure and services, and need for training as the top four constraints on their businesses (Chandra et al., 2002, p. 23) ${ }^{12}$. However, these are merely pointers: the central question is why unemployed persons do not enter the informal sector.

Historically the apartheid system repressed the informal activities of black South Africans through such restrictive legislation as the Group Areas Act, harsh licensing, strict zoning regulations, and effective detection and prosecution of offenders (Rogerson, 1992). Bouts of slum clearance and 
other periodic attacks on the illegal spaces within which informal enterprise thrived, served to rid South African cities of black-dominated informal sector niches that were construed as hazardous to public health and stereotyped as unsightly and unsanitary (Rogerson 1992). While these restrictions have been progressively lifted since the mid-1980s, there were lingering licensing controls and restrictive bye-laws in many urban centers at the time of the surveys ${ }^{13}$. Moreover, repression and disempowerment of Africans under apartheid would have inhibited the development of entrepreneurial and social skills and of social networks. These factors are important for confidence in entering the self-employed sector and for success in it.

The 1999 survey suggests that government support continued to be inadequate, particularly in relation to crime prevention, investment in infrastructure, and the provision of credit and training facilities (Chandra et al., 2002, Table A2.6, pp. 18, 20, 44-5). 30\% of the informal businesses had been victims of crime in the previous year, but the number of respondents expressing concern was double that figure $^{14} .81 \%$ of all informal sector operators (and $90 \%$ of the self-employed non-employers within that group) had never received any business assistance or training. The lack of training reflected the high cost: the few owners who had been trained had paid on average three times the average monthly earning of the sample for their training. $60 \%$ of the operators did not have access to the 'small business support centers' that had been established by central and local government. Xaba et al. (2002, p. 25) argue that the South African government's avowed support for small, medium and micro-enterprises (SMMEs) is concentrated on the formal sector and neglects the informal sector.

Labor market institutions such as Industrial Councils (now called Bargaining Councils) and Wage Boards set sectoral minimum wages and stipulate working conditions in many industries in South Africa. These minimum wages and stipulations are applied to all firms in the industry and region, irrespective of size, via the 'extension' provision. There are serious penalties for flouting the agreements of these institutions. Such provisions impose a burden of high labor costs on small firms and it is likely that they would seriously inhibit the entry and growth of such firms (Black and Rankin, 1998, p461). This is one explanation for the large average size of firms in South Africa. These institutional features may inhibit small firms but they should not inhibit individual entrepreneurship, i.e., owner-operators. 
Chandra et al. (2002, pp. 26,30) find that the informal sector operators had required substantial start-up capital (averaging over 2.5 times the average monthly earnings in the sample). New small businesses have to rely on their own financial resources: there was very little access to either formal or even informal credit; the overwhelming majority relied on their own savings or on funds from relatives or friends for start-up capital. The most important reasons given for not accessing formal credit markets were that the procedures were too complicated, the costs were too high, and that respondents lacked the required collateral.

Some of these problems are common to many developing countries, and do not help to explain why unemployment is so high in South Africa relative to informal sector employment. The factors which may set South Africa apart are the legacy of apartheid, the prevalence of crime and associated insecurity, the relative inadequacy of government support for the informal sector, and the lack of informal credit.

\section{CONCLUSION}

Unemployment in South Africa is so widespread that it demands an explanation. This paper has examined a central question about South African unemployment, increasingly recognized to be a quandary deserving attention (Cichello, et. al., 2002): why do the unemployed not enter the informal sector? The findings provide little support for the idea that unemployed people choose in any meaningful sense to be unemployed. We find that there is sharp earnings segmentation between the formal sector and the relatively small informal sector, and that the unemployed are substantially worse off even than the informally employed, in terms of both income and expenditure. This contradicts the luxury unemployment interpretation of joblessness, whereby higher household income reduces the incentive to become employed in the informal sector and increases the incentive to consume more leisure. It might be contended that, given the disutility of work, some people prefer to substitute leisure for higher monetary income, so that their apparent deprivation cannot be used to argue that they are constrained to be unemployed. However, if their unemployment is to be interpreted as voluntary, such people should be happier (or less unhappy) than if they were employed. Our findings show that households with a high proportion of unemployed persons are very substantially and significantly less 
satisfied with their quality of life than households with a high proportion of informally employed. They suggest that unemployment arises through impediments to entry into informal work, and they are at odds with the notion that unemployment is anything other than the better of two awful choices. Although this important issue deserves more research, we find various plausible reasons why the informal sector has been inhospitable to newcomers in South Africa.

In attempting to understand a crucial issue for South Africa, we encountered imperfect data. The quality of life questions are thus far only available at the household level; this information is more relevant at the individual level. Data on the distribution of consumption, and the sources of income, among members of the household would help to clarify the options available to the unemployed. A regular national panel household survey would help to overcome the problems of unobserved heterogeneity that have qualified our analysis, and would provide the longitudinal information on workers needed to understand more about the nature of unemployment and of informal sector employment, for instance by measuring the income changes resulting from transitions between employment states. A more precise reservation wage question is needed that collects information on expected hours of work per period, maximum acceptable distances to work, past wages, and past wage offers rejected, and which makes a dedicated attempt to obtain data on the minimum wage that would be acceptable for work rather than the expected, fair or bargaining wage. Finally, and most importantly, our arguments have pinpointed the need to understand the potential barriers to entry into the informal sector in South Africa: surveys of unemployed people that specifically address this issue are required.

It is likely that most currently unemployed workers in South Africa are involuntarily unemployed in the sense that they would accept formal sector jobs at the going wages. Although each unemployed worker voluntarily chooses not to enter free-entry activities, this may well be because incomes in the free-entry part of the informal sector are extremely low. However, there is no real choice. For as long as barriers to entry continue to restrict opportunities in much of the informal sector, this sector will be unable to absorb significantly more of the currently jobless. Unemployed workers face a high probability of remaining unemployed, whatever their search activity. The need for policies that would reduce unemployment in South Africa is compelling. Our diagnosis yields two main policy 
implications. Government should try to diminish labor market segmentation and to overcome the obstacles to entering the productive informal sector.

Although South African unemployment is extremely high, a number of developing countries have comparable rates. For instance, in various years in the 1990s, countries with high national unemployment rates in Africa included Algeria (30\%), Botswana (22\%), urban Ethiopia (39\%), urban Mauritania (32\%), Morocco (22\%), Zambia (25\%) and Zimbabwe (22\% in 1992 and estimated at 50\% in 1999); in Latin America, Argentina (19\%) and Colombia (21\%); and in Southern Europe, Armenia $(36 \%)$ and Macedonia $(39 \%)^{15}$. It is possible that our diagnosis applies also to some of these countries. There is a case for research to compare the South African labor market with those of similar economies which have either suffered or avoided high unemployment.

\footnotetext{
${ }^{1}$ Monday Paper, 16, 3, March 3-10, 1997, University of Cape Town, “Applications Stream in for Workers' Posts".

${ }^{2}$ Since domestic service is low-paid and was until very recently unprotected (often exploitative) employment, we consider domestic servants as informal workers even if they report themselves as 'regular' employees, as some of them do. Self-employed professionals are excluded from the definition of the informal sector and are assumed to be regular, formal sector workers.
}

${ }^{3}$ Bhorat (1999) rightly argues that the size of the informal sector in the early October Household surveys was underestimated because they counted as formally employed all those persons who work for someone else, even though some of these work for informally self-employed persons. From 1997 onwards, the OHSs rectified this omission. While this correction raised the estimated size of the informal sector substantially, it is still not a large share. For example, the informal sector estimated from OHS94 accounts for $14.7 \%$ of total employment, but from OHS97 and OHS98 for $24.4 \%$ and $21.9 \%$ respectively (also see Table 3). It is sometimes argued that the size of the informal sector in South Africa is underestimated and the unemployment rate overestimated because some people engaged in casual, small-scale self-employment or in illegal activities may not report these and they are counted as unemployed instead (Schlemmer and Levitz, 1998). However, Bhorat (1999) believes that the October Household surveys ask a detailed set of questions, making such underestimation of self-employment and overestimation of unemployment unlikely. Moreover, it is not clear that illegal activity such as theft (information on which is indeed likely to be suppressed) should be counted as employment. Such activity is to some extent 
endogenous, i.e., the effect of unemployment and of consequent destitution, an income transfer rather than a productive activity.

${ }^{4}$ While a comparison of OHS and LFS data shows that in general the share of informal employment in total employment has increased somewhat over the 1990s, Devey et. al. (2002) warn that the extent of the increase is uncertain and that the data they present "should therefore be treated with caution".

${ }^{5}$ The selection term lambda was significant at the 5\% level in the formal sector earnings equation. Here, as well as in estimations of selectivity-corrected earnings functions for other groups later in the paper, the selectivity term was well identified because of the availability of good identifying exclusion restrictions. The following household demographic variables were used in the first stage probit: married; head of household; household non-earned income; number of children; number of elderly persons aged $>=65$; number of household members (other than the individual) who are employed; and total household size.

${ }^{6}$ Selectivity-corrected earnings functions gave higher average predicted earnings from informal employment than did OLS earnings functions, irrespective of whether the selectivity term lambda was included in the prediction or not. Both approaches have been used in the literature. The lambda-inclusive approach is typically justified in studies that use it on the grounds that the dot product of all the regression variable means and their respective coefficients gives the mean of the observed wage. Some studies also include lambda owing to the erroneous belief that lambda is a measure of unobserved characteristics. The lambda-exclusive approach is used in many studies on the grounds that the role of the inclusion of lambda is simply to correct the bias in the remaining coefficients in an OLS regression and that constructed lambda itself is not a variable but rather a part of the error term. While the choice of model in Table 3 does not alter our inference - namely that predicted earnings in informal employment greatly exceed unemployed income - we would tend to favor the lambda-exclusive model since lambda is not a measure of unobserved characteristics: it is simply a monotonically decreasing function of the probability of being in informal employment. For individuals who have a high probability of being in informal employment, lambda is given a value close to zero, irrespective of their unobserved characteristics; for individuals who have a low probability, lambda is assigned a high value. Thus, while one might infer something about a person's unobserved traits from the value of lambda at low values of the observed variables, one cannot infer anything about unobserved traits at high values of observed variables. For a review of the two approaches see Schaffner (1998) and Vella (1988).

${ }^{7}$ When using individual-level data in the initial runs, the household's quality-of-life code was assigned to each member in the household. The results were very similar to those reported in Table 7, and are available from the authors.

${ }^{8}$ The mid-point values attached to the 5 duration categories 'less than 1 month', 'between 1 and 6 months', ' 6 months to 1 year', ' 1 to 3 years' and 'greater than 3 years' were $0.5,3.5,9.0,24$, and 48 months respectively. It is unfortunate that the last category is truncated at 3 years since a high proportion of all unemployed people fall in this category and many of them may suffer unemployment for much longer periods than 3 years. There is a loss of information and of variability in the duration variable because of this truncation. However, this is better than the 
duration information available in the OHS94 dataset where the truncation occurs at 1 year and where more than two-thirds of the unemployed were unemployed for more than 1 year!

${ }^{9}$ When log of per capita household expenditure is instrumented by household assets, the coefficient on the instrument is close to zero. In other words, there is no positive relationship between prosperity and unemployment duration. These results are available from the authors.

${ }^{10}$ For instance, Nattrass (2002) found that in the Khayelitsha/Mitchell's Plain survey of 2000, which contained several detailed reservation wage questions, the reservation wage responses by the unemployed were inconsistent; this highlights the difficulty of designing and implementing appropriate questions.

${ }^{11}$ The analysis, with its negative results, is presented in Kingdon and Knight (2001b).

${ }^{12}$ In a survey of black households in Soweto in 1999, Piazza-Giorgi (2001) found that similar concerns were expressed, the most frequently reported being (in order) crime, unfair competition, lack of education and training, lack of access to credit, and poor infrastructure.

${ }^{13}$ A 1999 government document titled 'Ideas Paper No. 1: South African Labour Market and Job Creation' states that many local governments still put obstacles in the way of the self-employed and informal sector, or fail to provide the planning support and facilities needed for them to thrive.

${ }^{14}$ The prevalence of violence and insecurity in the informal sector is stressed also by Kaplinsky (1995) and Manning and Mashigo (1993).

${ }^{15}$ Source: ILO (2000, 2001 - from labor force surveys) except Ethiopia (Krishnan et. al., 1998); Mauritania (Charmes, 2000); Zambia (SADC quoted in www.germanchamber.co.za/sadc.htm) and Zimbabwe (CSO, 1994, p99) and SADC quoted in www. germanchamber.co.za/files/sadc.htm. 


\section{REFERENCES}

Banerjee, B. (1986). Rural to Urban Migration and the Urban Labour Market: A Case Study of Delhi, Bombay: Himalaya Publishing House.

Benjamin, D. \& Kochin, L. (1979). Searching for an Explanation of Unemployment in Interwar Britain, Journal of Political Economy, 87, 441-470.

Bhorat, H. (1999). The October Household Survey, Unemployment and the Informal Sector: A Note. South African Journal of Economics, 67(2), 320-326.

Black, P. A. \& Rankin, N. (1998). On the Cost-Increasing Effect of the New Labour Laws in South Africa. South African Journal of Economics, 66(4), 452-63.

Blanchflower, D. \& Oswald, A. (1999). Well-being over time in Britain and the USA. Economics Department, Warwick University, mimeo, November, 1999.

Chandra, V., J. Nganou and C. Noel (2002) Constraints to Growth in Johannesburg's Black Informal Sector: Evidence from the 1999 Informal Sector Survey. World Bank Report No. 24449-ZA, June.

Charmes, J. (2000). Informal sector, poverty and gender: A review of empirical evidence: Background paper for World Development Report 2001. Centre of Economics and Ethics for Environment and Development, University of Versailles-St Quentin en Yvelines.

Cichello, P., G. Fields and M. Leibbrandt (2002). Earnings and Employment Dynamics for Africans in Post-Apartheid Kwazulu Natal. Paper presented at the DPRU conference on Labour Markets and Poverty in South Africa, Johannesburg, October 22-24, 2002.

Clark, A. E. \& Oswald, A. (1994). Unhappiness and Unemployment. Economic Journal, 104 (424), 64859.

Collins, M. (1982). Unemployment in Interwar Britain: Still Searching for an Explanation. Journal of Political Economy, 90(2), 369-79.

Crafts, N. F. R. (1985). Long Term Unemployment in Britain in the 1930s. Economic History Review, 40(3), 418-32.

Cross, R. (1982). How much Voluntary Unemployment in Interwar Britain?. Journal of Political Economy, 90(2), 380-85.

CSO (1994). Census 1992: Zimbabwe National Report. Harare: Government of Zimbabwe.

Devey, R. Skinner, C. \& Valodia, I. (2002). The Informal Economy in South Africa: Who, Where, What and How Much?. Paper presented to the DPRU Conference on Labour Markets and Poverty in South Africa, Johannesburg, 22-24 October, 2002. Forthcoming in Transformation.

Di Tella, R., McCulloch, R. \& Oswald, A. (1998). The Macroeconomics of Happiness. Paper presented at the Conference on The Labour Market: Stocks and Flows, Institute of Economics and Statistics, University of Oxford, 28-29 September, 1998.

Gerson, J. (1981). The Question of Structural Unemployment in South Africa. South African Journal of Economics, 49(1), 10-25.

Harris, J. \& Todaro, M. (1970). Migration, Unemployment, and Development: A Two-Sector Analysis. American Economic Review, 60(1), 126-42. 
Harris, J. \& Sabot, R. (1982). Urban Unemployment in LDCs: Towards a More General Search Model. chapter 2 in Sabot, R. (ed.) Migration and the Labor Market in Developing Countries. Boulder: Westview Press.

ILO (1996). Restructuring the Labour Market: The South African Challenge: An ILO Country Review. Geneva: International Labour Office.

ILO (2000, 2001). Yearbook of Labour Statistics. Geneva: International Labour Office.

Kantor, B. (1980). Blacks: Is there Unemployment?. Businessmen's Law, 9, 104-7, 143-44.

Kaplinsky, R. (1995). Capital Intensity in South African Manufacturing and Unemployment, 1972-90. World Development, 23(2), 179-92.

Kingdon, G.G. \& Knight, J.B. (1999). Unemployment and Wages in South Africa: A Spatial Approach. Centre for the Study of African Economies Working Paper No. WPS/99-12, Oxford.

Kingdon, G.G. \& Knight, J.B. (2000). Are Searching and Non-Searching Unemployment Distinct States when Unemployment is high? The Case of South Africa. Centre for the Study of African Economies Working Paper No. WPS/2000-2, Oxford.

Kingdon, G.G. \& Knight, J.B. (2001a). Race and the Incidence of Unemployment in South Africa. Centre for the Study of African Economies, Working Paper No. WPS/2001-18, University of Oxford.

Kingdon, G.G. \& Knight, J.B. (2001b). Unemployment in South Africa: The Nature of the Beast. Centre for the Study of African Economies, Working Paper No. WPS/2001-15, University of Oxford.

Knight, J. B. (1982). The Nature of Unemployment in South Africa. South African Journal of Economics, 50(1), 1-12

Krishnan, P., Selassie, T. \& Dercon, S. (1998). The Urban Labour Market during Structural Adjustment: Ethiopia 1990-1997. Centre for the Study of African Economies Working Paper WPS/98-9, Oxford.

Kulshreshtha, A. C. \& Singh, G. (1998). Contribution of Informal Sector in the Indian Economy. New Delhi: Central Statistical Organisation.

Layard, R., Nickell, S. \& Jackman, R. (1991). Unemployment: Macroeconomic Performance and the Labour Market. Oxford: Oxford University Press.

Maloney, W. (1999). Does Informality Imply Segmentation in Urban Labor Markets? Evidence from Sectoral Transitions in Mexico. World Bank Economic Review, 13, 275-302.

Maloney, W. (2002) Informality Revisited. Mimeo, World Bank.

Manning, C. \& Mashigo, A. (1993). Manufacturing in Microenterprises in South Africa. COSATU/Economic Trends Group Industrial Strategy Project Research Report, Development Policy Research Unit, University of Cape Town.

Metcalf, D., Nickell, S. \& Floros, N. (1982). Still Searching for an Explanation of Unemployment in Interwar Britain. Journal of Political Economy, 90(2), 386-99.

Moll, P. (1996). The Collapse of Primary Schooling Returns in South Africa 1960-90. Oxford Bulletin of Economics and Statistics, 58(1), 185-209. 
Nattrass, N. (2002). Unemployment, Employment and Labour Force Participation in Khayelitsha/Mitchell's Plain. Centre for Social Science Research Working Paper No. 12, University of Cape Town.

Ormerod, P. \& Worswick, G. D. N. (1982). Unemployment in Interwar Britain. Journal of Political Economy, 90(2), 400-09.

Piazza-Giorgi, B. (2001). A Profile of the Self-Employed in Soweto in Mid-1999, with Gender Disaggregation: A Report on a Field Survey. ERSA Policy Paper No. 15.

Rogerson, C.M. (1992). The Absorptive Capacity of the Informal Sector in the South African City. In D. M. Smith, The Apartheid City and Beyond. London: Routledge.

Schaffner, J. A. (1998). Generating Conditional Expectations From Models with Selectivity Bias: Comment. Economics Letters, 58, 255-61.

Schlemmer, L. \& Levitz, C. (1998). Unemployment in South Africa: The Facts, the Prospects, and an Exploration of Solutions. Johannesburg: South African Institute of Race Relations.

Simkins, C. (1982). Structural Unemployment Revisited, SALDRU Fact Sheet No. 1, University of Cape Town.

StatsSA (1998). Unemployment and Employment in South Africa, Pretoria: Statistics South Africa.

StatsSA (2002). Labour Force Survey Statistical Release PO210. http://www.statssa.gov.za.

Stigler, G. (1962). Information in the Labor Market. Journal of Political Economy, 70 (supplement).

Theodossiou, I. (1998). The effects of Low Pay and Unemployment on Psychological Well-being: A Logistic Regression Approach. Journal of Health Economics, 17, 85-104.

Vella, F. (1988). Generating Conditional Expectations From Models with Selectivity Bias. Economics Letters, 28, 97-103.

Warr, P.B., Jackson, P.R. \& Banks, M. (1988). Unemployment and Mental Health: Some British Studies. Journal of Social Issues, 44, 47-68.

Wilson, F. \& Ramphele, M. (1989). Uprooting Poverty: The South African Challenge. London: W.W. Norton \& Co.

Wittenberg, M. (2002). Formal and Informal Work in South Africa: Evidence from the South African Time Use Survey, paper presented to the DPRU Conference on Labour Markets and Poverty in South Africa, Johannesburg, 22-24 October, 2002.

Xaba, J., P. Horn, and S. Motala (2002). The Informal Sector in Sub-Saharan Africa. ILO Working Paper on the Informal Economy, Employment Sector, ILO, Geneva. 
Table 1

Unemployment and informal employment

\begin{tabular}{|c|c|c|c|}
\hline & $\begin{array}{c}\text { Urban } \\
\text { unemployment rate }\end{array}$ & $\begin{array}{l}\text { Employment rate } \\
\quad \text { in the } \\
\text { informal sector(3) }\end{array}$ & $\begin{array}{c}\text { Ratio of informal sector } \\
\text { employment to } \\
\text { unemployment }\end{array}$ \\
\hline South Africa & 29.3 & 18.9 & 0.7 \\
\hline \multicolumn{4}{|l|}{ Other Sub-Saharan } \\
\hline $\operatorname{Africa}(1)$ & 16.0 & 74.8 & 4.7 \\
\hline Benin & 10.1 & 92.8 & \\
\hline Burkina Faso & -- & 77.0 & \\
\hline Chad & -- & 74.2 & \\
\hline Guinea & 12.3 & 71.9 & \\
\hline Kenya & 16.2 & 71.6 & \\
\hline Mali & 9.9 & 78.6 & \\
\hline Mauritania & 31.6 & 75.3 & \\
\hline Mozambique & -- & 73.5 & \\
\hline Zambia & -- & 58.3 & \\
\hline Latin America(1)(2) & 8.1 & 56.9 & 7.0 \\
\hline Argentina & 18.8 & 53.3 & \\
\hline Bolivia & 3.6 & 63.6 & \\
\hline Brazil & 4.6 & 57.6 & \\
\hline Colombia & 9.0 & 55.5 & \\
\hline Ecuador & 6.9 & 53.5 & \\
\hline Mexico & 6.3 & 59.4 & \\
\hline Paraguay & 5.6 & 65.5 & \\
\hline Venezuela & 10.3 & 46.9 & \\
\hline $\operatorname{Asia}(1)$ & 5.3 & 63.0 & 11.9 \\
\hline India & -- & 73.7 & \\
\hline Indonesia & 7.2 & 77.9 & \\
\hline Pakistan & 6.1 & 64.6 & \\
\hline Philippines & 7.4 & 66.9 & \\
\hline Thailand & 0.4 & 51.4 & \\
\hline Iran & -- & 43.5 & \\
\hline
\end{tabular}

Sources : Taken from Charmes (2000), Table 1. Charmes reports that his labor force figures are taken from the World Development Indicators, 1997 and that the figures are personal compilations of the author and are "based on official figures (published or unpublished) for National Accounts".

Notes: (1) Non-weighted arithmetical means. (2) Informal employment estimates for 1995. (3) As a share of total nonagricultural employment.

Charmes does not specify the definition of unemployment used for the included countries but it seems to be the standard ILO-recommended definition for most countries. In any case, in most countries, the gap between the narrowly and broadly defined unemployment rates is small. In South Africa, however, Charmes seems to have used the 'broad' definition of unemployment. If the narrow definition is used, urban unemployment in South Africa in 1995 was $15.7 \%$ rather than $29.3 \%$ (StatsSA, 1998) and, thus, the ratio of non-agricultural informal employment to unemployment would be 1.2 instead of 0.7 . However, by 1998, the narrowly measured unemployment in South Africa was $26 \%$ with apparently little change in the size of the informal sector, so that the ratio in 1998 is of the order of 0.7.

Since much of the agricultural labor force in developing countries is engaged in small-scale or subsistence agriculture, the share of the informal sector in the agricultural labor force is expected to be even greater than that in the nonagricultural labor force reported here. For example, for India, the share of the informal sector in the non-agricultural labor force is $79 \%$ but its share in the total labor force is $92 \%$ (Kulshreshtha and Singh, 1998). 
Table 2

Percentage distribution of 'broad' labor force participants into unemployed, informal workers, and formal workers, by gender, region, and race

SALDRU 1993 data

\begin{tabular}{|c|c|c|c|c|c|}
\hline & \multirow{2}{*}{$\begin{array}{c}\text { Unemployed } \\
\text { (a) }\end{array}$} & \multirow{2}{*}{$\begin{array}{c}\text { Informally } \\
\text { employed } \\
\text { (b) }\end{array}$} & \multirow{2}{*}{$\begin{array}{l}\text { Formally } \\
\text { employed } \\
\text { (c) }\end{array}$} & \multicolumn{2}{|c|}{$\begin{array}{c}\text { Total } \\
(\mathbf{a}+\mathbf{b}+\mathbf{c})\end{array}$} \\
\hline & & & & $\%$ & $\mathbf{N}$ \\
\hline \multicolumn{6}{|l|}{ Rural } \\
\hline males & 35 & 13 & 52 & 100 & 3038 \\
\hline females & 48 & 25 & 27 & 100 & 2671 \\
\hline total & 41 & 18 & 41 & 100 & 5754 \\
\hline \multicolumn{6}{|l|}{ Urban } \\
\hline males & 21 & 15 & 64 & 100 & 4121 \\
\hline females & 27 & 26 & 47 & 100 & 3441 \\
\hline total & 24 & 20 & 56 & 100 & 7562 \\
\hline \multicolumn{6}{|c|}{ Rural+urban } \\
\hline males & 27 & 14 & 59 & 100 & 7204 \\
\hline females & 36 & 25 & 38 & 100 & 6112 \\
\hline total & 31 & 19 & 50 & 100 & 13316 \\
\hline \multicolumn{6}{|l|}{ Race } \\
\hline African & 39 & 21 & 40 & 100 & 9578 \\
\hline Coloured & 21 & 15 & 64 & 100 & 1302 \\
\hline Indian & 11 & 15 & 73 & 100 & 451 \\
\hline White & 5 & 14 & 81 & 100 & 1985 \\
\hline total & 31 & 19 & 50 & 100 & 13316 \\
\hline
\end{tabular}


Table 3

Share of informal employment in total labor force, by definition of labor force

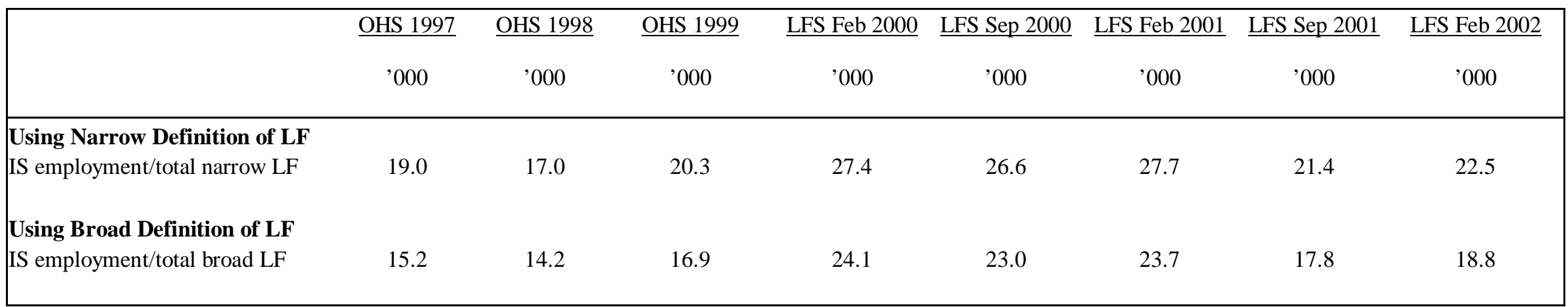

Note: IS is short form for informal sector; LF is short form for labor force.

Source: Computed from Statistical Release P0210 (StatsSA, 2002), and from Statistics South Africa figures presented in Devey, Skinner, and Valodia (2002). 
Table 4

Labor market status and Socio-economic situation

SALDRU93 data

\begin{tabular}{|c|c|c|c|}
\hline & Unemployed & $\begin{array}{c}\text { Informally } \\
\text { employed }\end{array}$ & $\begin{array}{l}\text { Formally } \\
\text { employed }\end{array}$ \\
\hline Household unemployment rate & 0.751 & 0.134 & 0.105 \\
\hline \multicolumn{4}{|l|}{ Per capita household income:(Rand/month) } \\
\hline - mean & 185.68 & 594.50 & 989.90 \\
\hline - median & 104.26 & 200.00 & 549.25 \\
\hline \multicolumn{4}{|c|}{ Per capita household expenditure: (Rand/month) } \\
\hline - mean & 221.02 & 458.55 & 772.15 \\
\hline - median & 147.30 & 242.02 & 440.53 \\
\hline \multicolumn{4}{|l|}{ Other indicators: } \\
\hline Remittance income/total income & 0.17 & 0.07 & 0.01 \\
\hline Other non-earned income/total income & 0.26 & 0.10 & 0.04 \\
\hline Below international poverty line of $\$ 1$ a day & 0.45 & 0.30 & 0.08 \\
\hline Number of assets* & 3.16 & 4.11 & 5.25 \\
\hline Years of education & 7.06 & 6.66 & 8.51 \\
\hline African & 0.90 & 0.78 & 0.58 \\
\hline Household size & 7.01 & 5.38 & 4.70 \\
\hline Age & 30.74 & 37.85 & 36.73 \\
\hline \multicolumn{4}{|l|}{ Perception of well-being: } \\
\hline Dissatisfied or very dissatisfied with life & 0.73 & 0.57 & 0.46 \\
\hline $\begin{array}{l}\text { Thinks that the most important help by govt. } \\
\text { would be help with jobs }\end{array}$ & 0.65 & 0.51 & 0.44 \\
\hline \multicolumn{4}{|l|}{ Living conditions: } \\
\hline Lives in a house/part of house & 0.50 & 0.56 & 0.66 \\
\hline Number of household members per room & 1.95 & 1.61 & 1.27 \\
\hline Dwelling has corrugated iron roof & 0.65 & 0.60 & 0.45 \\
\hline Piped water within or tap in yard & 0.43 & 0.61 & 0.75 \\
\hline Has to fetch water daily & 0.53 & 0.36 & 0.22 \\
\hline Distance to water (meters) & 260.90 & 174.14 & 83.61 \\
\hline Dwelling has flush toilet & 0.33 & 0.50 & 0.68 \\
\hline Dwelling has electricity connection & 0.35 & 0.52 & 0.71 \\
\hline \multicolumn{4}{|l|}{ Community characteristics: } \\
\hline Urban & 0.43 & 0.58 & 0.65 \\
\hline Homeland & 0.59 & 0.41 & 0.24 \\
\hline Number of facilities in community & 2.90 & 3.43 & 5.80 \\
\hline Distance to facilities from home & 98.89 & 74.37 & 65.17 \\
\hline Community has tarred roads & 0.15 & 0.28 & 0.43 \\
\hline Roads impassable at certain times of year & 0.51 & 0.43 & 0.27 \\
\hline $\mathrm{N}$ (\% of labor force) & $4154(31 \%)$ & $2542(19 \%)$ & $6620(50 \%)$ \\
\hline
\end{tabular}

Notes: Apart from 'years of education', age and community characteristics, all above variables are coded at the household level in the dataset. For the purposes of this table, however, we have assigned the value of the household variable to each individual member of the household. Then we take the sub-sample of persons in each labor market 'state' and average the variables across individuals in that state. Similarly, the community variables are assigned to each individual living in that community before averaging across unemployed individuals in a given state. The very high household unemployment rate in the first column indicates that unemployed people are likely to live in households where other members are unemployed as well. *Number of assets owned by the family from among the following list: motor vehicle, bicycles, radio, electric stove, gas stove, fridge, primus cooker, TV, geyser, electric kettle, and telephone. 
Table 5

Average of predicted earnings of unemployed persons, SALDRU93 data

\begin{tabular}{|lcc|}
\hline Wage equation & $\begin{array}{c}\text { In informal } \\
\text { self-employment }\end{array}$ & $\begin{array}{c}\text { In casual } \\
\text { wage employment }\end{array}$ \\
\hline OLS & 267 & 286 \\
\hline Selectivity-corrected $(\lambda$ _exclusive prediction) & 363 & 389 \\
\hline Selectivity-corrected $(\lambda$ _inclusive prediction) & 437 & 430 \\
\hline
\end{tabular}

Note: See endnotes 5 and 6 for a description of the identification strategy in the selectivity corrected earnings equations and for a discussion of the justifications for inclusion/exclusion of the selectivity term when predicting earnings for unemployed persons.

Table 6

Marginal product of labor in self-employment, SALDRU93 data

\begin{tabular}{|lccr|}
\hline & $\begin{array}{c}\text { Marginal product of labor } \\
\text { in self-employment }\end{array}$ & $\begin{array}{c}\text { Monthly per capita } \\
\text { income in } \\
\text { unemployment }\end{array}$ \\
\hline Median & With capital & Without capital & \\
\hline Mean & 188 & 160 & 104 \\
\hline
\end{tabular}

Notes: For self-employed persons whose businesses used any capital, log of (value of) output was regressed on log of (value of) input and on logs of capital and labor hours. Other variables were years of education and region (urban and homeland). The adjusted R-square was 0.695 . The mean (median) marginal product of labor was calculated by multiplying the coefficient on log of labor by the mean (median) of ratio of output to labor. This yielded a MPL of $\mathrm{R}$ 187.91 per month on the basis of 40 hours work per week and 4.3 weeks per month. 
Table 7

Impact of unemployment and informal employment on perceived quality of life

SALDRU - Household level averaged data

\begin{tabular}{|c|c|c|c|c|c|c|c|c|c|}
\hline Variable & Coefficient & $\begin{array}{l}\text { Robust } \\
\text { t-value }\end{array}$ & $\begin{array}{l}\text { Marginal } \\
\text { effect** }\end{array}$ & Coefficient & $\begin{array}{l}\text { Robust } \\
\text { t-value }\end{array}$ & $\begin{array}{c}\text { Marginal } \\
\text { effect*** }\end{array}$ & Coefficient & $\begin{array}{l}\text { Robust } \\
\text { t-value }\end{array}$ & $\begin{array}{l}\text { Marginal } \\
\text { effect** }\end{array}$ \\
\hline Household unemployment rate & -0.326 & -6.40 & -0.117 & -0.307 & -5.38 & -0.110 & -0.437 & -7.97 & -0.157 \\
\hline HH informal employment rate & & & & 0.038 & 0.73 & 0.014 & -0.043 & -0.86 & -0.015 \\
\hline Age & -0.030 & -2.79 & -0.011 & -0.030 & -2.75 & -0.011 & -0.027 & -2.51 & -0.010 \\
\hline Age square & 0.000 & 2.71 & 0.000 & 0.000 & 2.67 & 0.000 & 0.000 & 2.43 & 0.000 \\
\hline Education : primary* & -0.017 & -0.28 & -0.006 & -0.017 & -0.28 & -0.006 & -0.004 & -0.06 & -0.002 \\
\hline junior* & 0.018 & 0.29 & 0.007 & 0.020 & 0.32 & 0.007 & 0.053 & 0.84 & 0.019 \\
\hline secondary* & 0.091 & 1.46 & 0.033 & 0.094 & 1.51 & 0.034 & 0.153 & 2.39 & 0.055 \\
\hline higher* & 0.580 & 5.88 & 0.208 & 0.585 & 5.90 & 0.210 & 0.655 & 6.46 & 0.235 \\
\hline Training* & -0.392 & -4.55 & -0.141 & -0.390 & -4.54 & -0.140 & -0.381 & -4.48 & -0.137 \\
\hline Migrate* & 0.206 & 1.70 & 0.074 & 0.207 & 1.70 & 0.074 & 0.223 & 1.79 & 0.080 \\
\hline HH pc income Quartile2 & 0.016 & 0.36 & 0.006 & 0.021 & 0.47 & 0.008 & & & \\
\hline Quartile3 & 0.242 & 3.73 & 0.087 & 0.252 & 3.87 & 0.090 & & & \\
\hline Quartile4 & 0.285 & 3.53 & 0.102 & 0.298 & 3.53 & 0.107 & & & \\
\hline Lives in owned home* & 0.120 & 2.73 & 0.043 & 0.120 & 2.73 & 0.043 & 0.115 & 2.61 & 0.041 \\
\hline Number of children $<16$ in $\mathrm{HH}$ & 0.003 & 0.34 & 0.001 & 0.004 & 0.41 & 0.002 & -0.014 & -1.43 & -0.005 \\
\hline Number of elderly $>64$ in $\mathrm{HH}$ & 0.030 & 0.98 & 0.011 & 0.029 & 0.96 & 0.011 & 0.030 & 1.00 & 0.011 \\
\hline Urban* & -0.201 & -2.23 & -0.072 & -0.205 & -2.30 & -0.074 & -0.179 & -2.07 & -0.065 \\
\hline Male* & -0.026 & -0.56 & -0.009 & -0.020 & -0.44 & -0.007 & -0.013 & -0.28 & -0.005 \\
\hline African* & -0.935 & -8.74 & -0.335 & -0.935 & -8.74 & -0.335 & -0.967 & -8.47 & -0.347 \\
\hline Coloured* & -0.432 & -3.65 & -0.155 & -0.429 & -3.63 & -0.154 & -0.444 & -3.69 & -0.159 \\
\hline Indian* & -0.253 & -2.33 & -0.091 & -0.254 & -2.34 & -0.091 & -0.248 & -2.30 & -0.089 \\
\hline Racial minority in community* & 0.178 & 1.78 & 0.064 & 0.173 & 1.76 & 0.062 & 0.182 & 1.85 & 0.065 \\
\hline Homeland* & 0.003 & 0.02 & 0.001 & -0.002 & -0.02 & -0.001 & 0.009 & 0.08 & 0.003 \\
\hline Cluster controls & & yes & & & yes & & & yes & \\
\hline Province dummies & & yes & & & yes & & & yes & \\
\hline $\mathrm{N}$ & & 7212 & & & 7212 & & & 7212 & \\
\hline $\log L$ & & -9717.66 & & & -9716.27 & & & -9741.80 & \\
\hline Restricted LogL & & -10657.14 & & & -10657.14 & & & -10657.14 & \\
\hline Pseudo R-square & & 0.0882 & & & 0.0883 & & & 0.0859 & \\
\hline
\end{tabular}

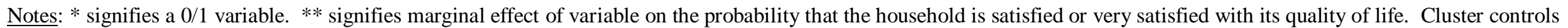
include cluster crime rate, cluster food-price index, and a dummy for whether cluster has roads that become impassable at certain times of the year. Omitted categories are no education, no pre-employment vocational training, non-migrant, lowest household per capita income quartile, non-owned home, rural, female, white race, non-minority and nonhomeland. 
Table 8

Percentage distribution of duration of unemployment, OHS97 data

\begin{tabular}{|llccc|}
\hline \multicolumn{1}{|r}{ Uncompleted duration } & Frequency & Percent & Cumulative percent \\
\hline $0-1$ & months & 1012 & 6.3 & 6.3 \\
$1-6$ & months & 1694 & 10.6 & 16.9 \\
$6-12$ & months & 2794 & 17.5 & 34.4 \\
$12-36$ months & 4574 & 28.7 & 63.1 \\
$>36$ & months & 5891 & 36.9 & 100.0 \\
\hline All & & 15965 & 100.0 & 100.0 \\
\hline
\end{tabular}




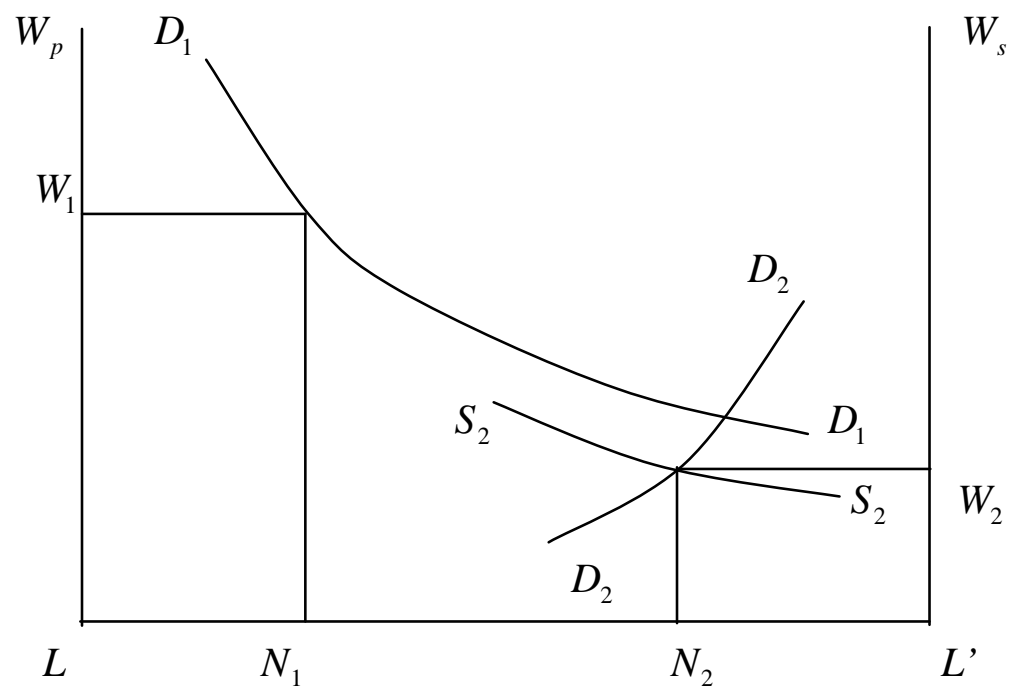

Figure 1

The formal and informal sector of the labor market

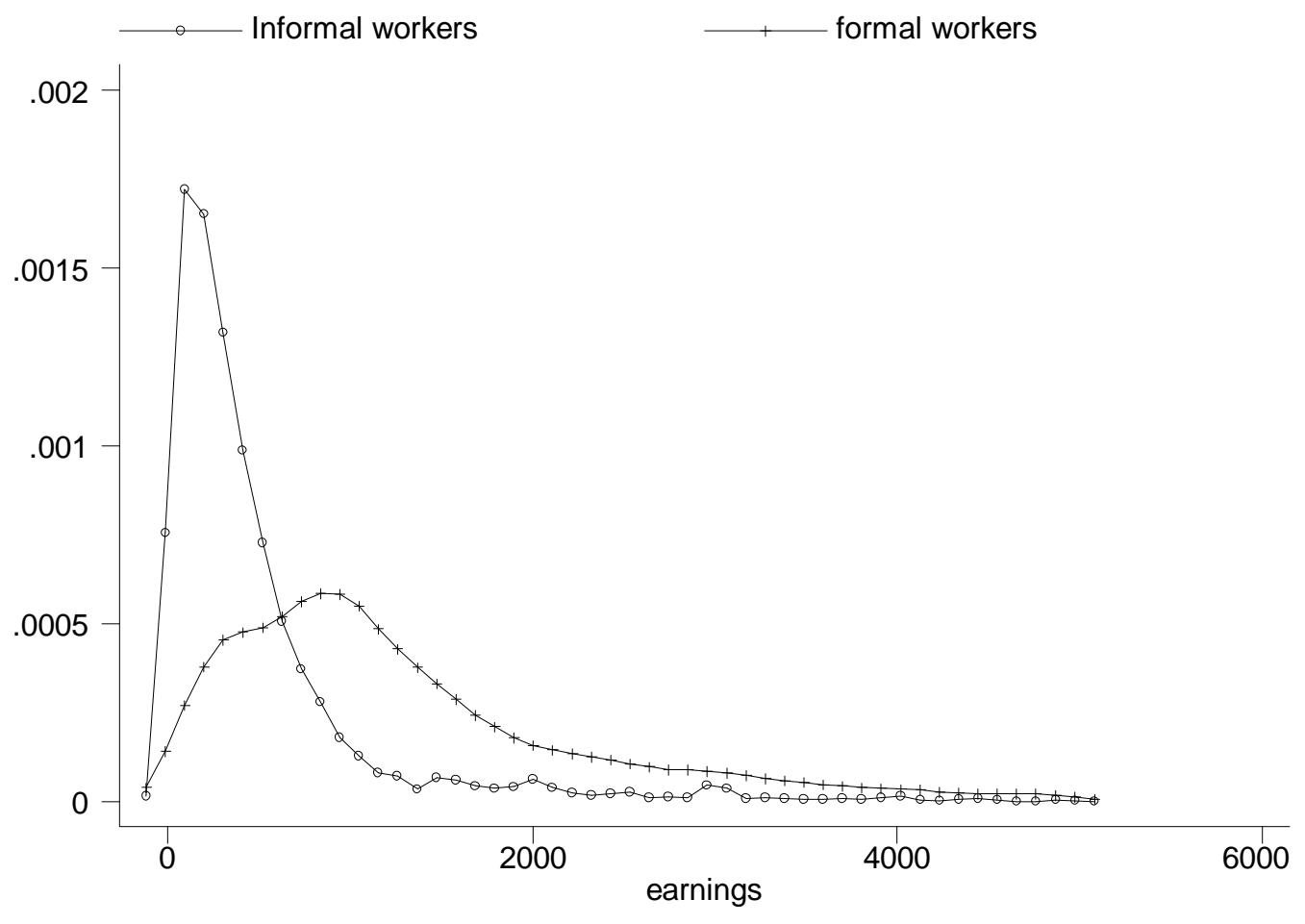

Rands/month

Figure 2

Epanechnikov kernel density of monthly earnings

(The area under each curve is equal to 1.0) 